\title{
SOPO BATAK TOBA RESILIENCE TECTONICS TOWARD EARTHQUAKE STUDY OBJECT: SOPO NAGARI SIHOTANG
}

\author{
${ }^{1}$ Jansen Chandra. ${ }^{2} J o n a t h a n$ Hans Yoas Sihotang, S.T., M. Arch. \\ I Student in the Bachelor's (S-1) Study Program in Architecture \\ at Parahyangan Catholic University \\ ${ }^{2}$ Senior lecturer in the Bachelor's (S-1) Study Program in Architecture \\ at Parahyangan Catholic University
}

\begin{abstract}
Sopo is a granary house in traditional Batak Toba architecture. Sopo is important for Batak Toba community because it serves as a place to store rice which is the source of life. Nowadays sopo is harder to find than ruma. Most of the sopo has transformed into Batak Toba house and uses as a residence. Sopo is located in Lake Toba, North Sumatra, which is prone to earthquakes. Sopo Nagari Sihotang was built in the 1920s and has experienced many earthquakes, now the sopo still survive without any structural damage. The resistance of the sopo over the years proves the sopo resilience to earthquakes. From the evidence of resilience to earthquake, its interesting to investigate the tectonics of this sopo. The purpose of the research is to understand the tectonic of Sopo Nagari Sihotang that resilience to earthquake and find local wisdom in facing earthquake disaster.

The research used descriptive method with qualitative approach by describing the existing state of Sopo Nagari Sihotang and comparing it with tectonic theory and earthquake resistant structure. The sopo's data were collected by field observation and literature study. The data are grouped into four parts, namely construction, detail, space, and ornaments that become points for analysis of tectonics. Tectonic analysis is associated with the theory of earthquake resistant structures to find out what makes tectonic of the sopo resilient to earthquakes.

The result is the tectonic resilience of the Sopo Nagari Sihotang to earthquakes are found in the tectonics construction in the use of materials; tectonics detail on vertical structures and horizontal structures; and tectonics space at the story height - the activity, the spatial form - the building hape, the spatial form - the structure, and the activity - the structure. The tectonic resilience of Sopo Nagari Sihotang to earthquakes is not found in the tectonics construction and tectonics ornament. The local wisdom which are the main factors make the sopo resilience to earthquake are found on, the tectonics detail of the sopo post-batu ojahan can retain the sopo by relying on the frictional force resulting from self-weight of the sopo; the tectonics detail of the sopo post-ransang can bind every sopo posts; the use of lightweight wood materials thus reducing inertia forces.
\end{abstract}

Key Words: resilience, tectonics, sopo, earthquake, Batak Toba

\section{RESILIENSI TEKTONIKA SOPO BATAK TOBA TERHADAP GEMPA BUMI OBJEK STUDI: SOPO NAGARI SIHOTANG}

\author{
${ }^{1}$ Jansen Chandra. ${ }^{2}$ Jonathan Hans Yoas Sihotang, S.T., M. Arch. \\ ${ }^{1}$ Mahasiswi S1 Program Studi Arsitektur Universitas Katolik Parahyangan \\ ${ }^{2}$ Dosen Pembimbing S1 Program Studi Arsitektur Universitas Katolik Parahyangan
}

\begin{abstract}
Abstrak- Sopo adalah rumah lumbung dalam arsitektur tradisional Batak Toba. Sopo penting bagi masyarakat Batak Toba karena berfungsi sebagai tempat menyimpan padi yang merupakan sumber kehidupan. Saat ini sopo
\end{abstract}

\footnotetext{
${ }^{1}$ Corresponding Author: jansen.chandra@gmail.com
} 
lebih sulit untuk ditemukan dibandingkan ruma. Sebagian besar sopo sudah berubah bentuk menjadi rumah Batak Toba dan berfungsi sebagai rumah tinggal. Sopo berada di Danau Toba, Sumatra Utara yang merupakan daerah rawan gempa bumi. Sopo Nagari Sihotang dibangun tahun 1920-an dan sudah mengalami banyak gempa bumi, saat ini sopo masih berdiri tanpa mengalami kerusakan struktur. Ketahanan sopo ini selama bertahuntahun membuktikan bahwa sopo resiliensi terhadap gempa bumi. Dari bukti resiliensi terhadap gempa bumi tersebut, tektonika pada sopo ini menarik untuk diteliti. Tujuan penelitian untuk memahami tektonika Sopo Nagari Sihotang yang resiliensi terhadap gempa bumi dan menemukan kearifan lokal (local genuine) dalam menghadapi bencana gempa bumi.

Penelitian menggunakan metode deskriptif dengan pendekatan kualitatif dengan cara mendeskripsikan keadaan eksisting Sopo Nagari Sihotang dan membandingkannya dengan teori tektonika dan struktur tahan gempa. Data sopo dikumpulkan dengan cara observasi lapangan dan studi pustaka. Data dikelompokkan menjadi empat bagian, yaitu konstruksi, detail, ruang, dan ornamen yang menjadi poin pembahasan tektonika. Analisis tektonika dikaitkan dengan teori struktur tahan gempa untuk mencari tahu apa yang membuat tektonika sopo resiliensi terhadap gempa bumi.

Hasilnya adalah resiliensi tektonika Sopo Nagari Sihotang terhadap gempa bumi ditemukan pada tektonika konstruksi dalam penggunaan material; tektonika detail pada elemen struktur vertikal dan elemen struktur horizontal; dan tektonika ruang pada ketinggian ruang - aktivitas, bentuk ruang - bentuk bangunan, bentuk ruang - susunan struktur, dan bentuk ruang - susunan struktur. Resiliensi tektonika Sopo Nagari Sihotang terhadap gempa bumi tidak ditemukan pada tektonika konstruksi dalam pembebanan sopo dan tektonika ornamen. Temuan kearifan lokal yang merupakan faktor utama membuat sopo resiliensi terhadap gempa bumi ada pada, tektonika detail tiang sopo - batu ojahan dapat mempertahankan sopo dengan mengandalkan gaya gesek yang dihasilkan dari berat sendiri sopo; tektonika detail sambungan tiang sopo ransang dapat mengikat antar tiang sopo; penggunaan material kayu yang ringan sehingga mengurangi gaya inersia.

Kata Kunci: resiliensi, tektonika, sopo, gempa bumi, Batak Toba

\section{PENDAHULUAN}

Sopo merupakan sebutan dari rumah lumbung masyarakat Batak Toba. Sopo berfungsi sebagai bangunan tempat menyimpan lumbung padi. Bagi masyarakat Batak Toba, padi merupakan sumber kehidupan. Padi menjadi makanan utama bagi masyarakat. Masyarakat Batak Toba menghargai sopo, karena sopo adalah tempat menyimpan sumber kehidupan mereka, yaitu padi. Oleh karena itu, sopo penting bagi masyarakat Batak Toba dulu. Saat ini sopo lebih sulit untuk ditemukan dibandingkan ruma ${ }^{2}$. Sebagian besar sopo sudah berubah bentuk menjadi rumah Batak Toba dan berfungsi sebagai rumah tinggal. Untuk membangun ulang sopo susah karena membutuhkan material yang sukar dicari dan biaya yang mahal. Maka dari itu, sopo merupakan objek yang penting untuk diteliti sebelum punah.

Salah satu sopo yang belum mengalami banyak perubahan, masih memiliki struktur asli sopo, dan kondisinya masih terawat serta berdiri kokoh adalah Sopo Nagari Sihotang. Sopo ini dibangun sekitar tahun 1920-an, dan telah berumur hampir satu abad. Dengan umurnya yang sangat tua dan masih berdiri hingga saat ini, membuktikan bahwa Sopo Nagari Sihotang ini telah berhasil bertahan dari gempa bumi. Ketahanan sopo ini terhadap gempa bumi telah membuktikan bahwa sopo memiliki resiliensi terhadap gempa bumi.

Dari bukti resiliensi terhadap gempa bumi tersebut, tektonika pada sopo ini menarik untuk diteliti. Tujuan penelitian ini untuk memahami tektonika Sopo Nagari Sihotang yang resiliensi terhadap gempa bumi dan menemukan kearifan lokal (local genuine) pada Sopo Nagari Sihotang dalam menghadapi bencana gempa bumi. Objek penelitian ini berada di Desa Sampur Toba, Kecamatan Harian, Kabupaten Samosir, Provinsi Sumatera Utara.

\footnotetext{
${ }^{2}$ Rumah tinggal tradisional masyarakat Batak Toba
} 


\section{TINJAUAN PUSTAKA}

\subsection{Resiliensi}

Resiliensi adalah kemampuan untuk beradaptasi dan pulih kembali dari keadaan kritis atau sulit ${ }^{3}$. Jika digunakan dalam konteks arsitektur, maka resiliensi berarti kemampuan suatu bangunan atau infrastruktur untuk bertahan atau menghindar dari kerusakan sehingga tidak mengalami kehancuran total.

\subsection{Tektonika}

Secara etimologi, tektonika berasal dari kata tekton (Yunani) yang berarti tukang kayu atau builder. Kata tekton juga berkaitan dengan kata taksan dalam bahasa Sansekerta yang mengacu pada kerajinan atau keterampilan tukang kayu dalam menggunakan kapak ${ }^{4}$. Secara umum, kata tekton mengacu pada tukang yang memiliki keterampilan bekerja dengan melibatkan material kayu. Tektonika adalah ilmu atau seni dari membentuk (shaping), menghias (ornamenting), atau merakit (assembling) material dalam konstruksi bangunan ${ }^{5}$.

Tektonika dapat disimpulkan sebagai studi dalam dua konsep atau dua aspek. Tektonika mengkaji tentang hubungan antara desain dan konstruksi, sistem yang disusun dan massa yang terbentuk, detail arsitektur dan bangunan yang tersusun atas bagiannya, dan antara permukaan struktur yang terlihat dengan bagian tidak terlihat di belakangnya yang membuat bangunan tetap stabil.

Tektonika terbagi menjadi beberapa kategori, yaitu anatomy, construction, detail + intersection, place, representation + ornamentation, space, dan atectonic ${ }^{6}$. Pada penelitian ini, kategori tektonika yang digunakan untuk menganalisis resiliensi tektonika terhadap gempa bumi adalah sebagai berikut:

1. Construction (Konstruksi), studi terhadap maksud dan metode konstruksi serta material yang digunakan

2. Detail + Intersection (Detail), studi terhadap sambungan dan titik pertemuan penting lainnya yang merupakan susunan skala terkecil dari sebuah karya arsitektur

3. Space (Ruang), studi terhadap ruang yang terbentuk dengan konstruksi dan ekspresi bangunan.

4. Representation + Ornamentation (Ornamen), studi terhadap hubungan antara konstruksi bangunan yang sebenarnya yang dibutuhkan untuk menciptakan stabilitas dengan cladding atau ornamen yang digunakan untuk menutupinya dan menambah nilai estetika

\subsection{Struktur Tahan Gempa}

Gaya inersia sesuai dengan Hukum Gerak Kedua Newton, F=M×a di mana F adalah besarnya gaya inersia, $\mathrm{M}$ adalah massa bangunan, dan a adalah akselerasi gempa bumi ${ }^{7}$. Gaya inersia dapat dilemahkan dengan cara mengurangi massa bangunan. Torsi terjadi karena elemen struktur tidak diposisikan secara simetris dalam denah, atau pusat kekakuan struktur bangunan $(\mathrm{CoR} /$ center of rigidity) tidak berhimpit dengan pusat massa $(\mathrm{CoM} /$ center of

\footnotetext{
${ }^{3}$ Resilient Design Institute. (2013). Resilient Design Strategies. Diakses tanggal 2 Februari 2018, dari Resilient Design Institute: http://www.resilientdesign.org/resilient-design-strategies/, para. 2.

${ }^{4}$ Frampton, K. (1995). Studies in Tectonic Culture. Chicago: The MIT Press, hlm. 3.

${ }^{5}$ Ching, F. D. (2012). A Visual Dictionary of Architecture Second Edition. Canada: John Wiley \& Sons, Inc, hlm. 3 .

${ }^{6}$ Schwartz, C. J. (2017). A Taxonomy of Architectural Tectonics. Building Technology Educators' Society 2017 Conference:Poetics and Pragmatism (hal. 179-186). Des Moines: Lulu.com, hlm. 179.

${ }^{7}$ Charleson, A. (2008). Seismic Design for Architects. USA: Architectural Press, hlm. 15.
} 
mass $)^{8}$. Daktilitas adalah seberapa lama struktur dapat deformasi hingga pada akhirnya kehilangan kekuatan strukturnya saat terjadi guncangan gempa ${ }^{9}$

Prinsip dasar untuk menahan gaya gempa bumi adalah struktur bangunan harus dapat menahan gaya lateral ${ }^{10}$. Ketahanan lateral ini harus ada pada elemen struktur vertikal, elemen struktur horizontal, konfigurasi vertikal bangunan, dan konfigurasi horizontal bangunan.

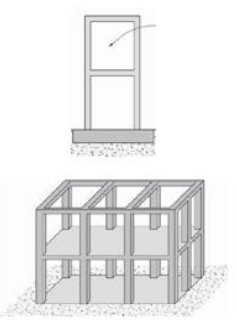

Moment frame

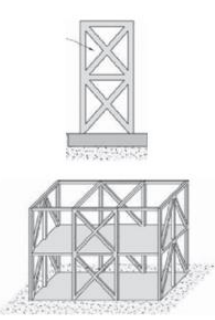

Braced frame

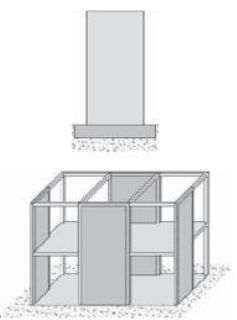

Shear wall

Figur 1 Elemen Struktur Vertikal

Sumber: (Charleson, 2008)

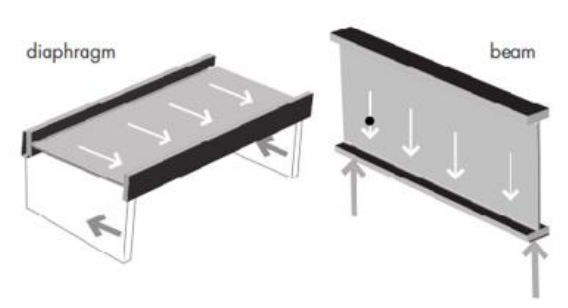

Figur 2 Elemen Struktur Horizontal Sumber: (Earthquake Engineering Research Institute, 2006)

Elemen struktur vertikal meliputi elemen kolom dan balok. Elemen struktur vertikal biasanya lemah dalam menahan gaya lateral, tergantung pada bagaimana desain elemen struktur vertikalnya ${ }^{11}$. Elemen struktur horizontal yang menahan gaya lateral disebut dengan diafragma. Elemen struktur yang merupakan diafragma lantai dan atap. Diafragma merupakan elemen yang penting untuk menahan gaya lateral. ${ }^{12}$. Konfigurasi melihat bagaimana struktur dan massa bangunan dapat saling berintegrasi dalam menahan gaya lateral. Ketidakteraturan konfigurasi horizontal, antara lain plan irregularity, re-entrant corner, diaphragm discontinuity, non-parallel system, dan mass irregularity ${ }^{13}$. Ketidakteraturan konfigurasi vertikal, yaitu soft story, short columns, dan vertical geometric irregularity ${ }^{14}$.
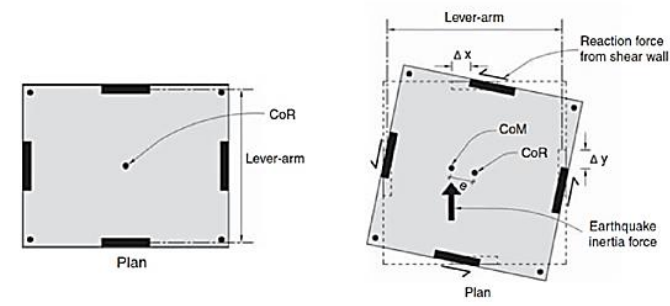

Plan irregularity

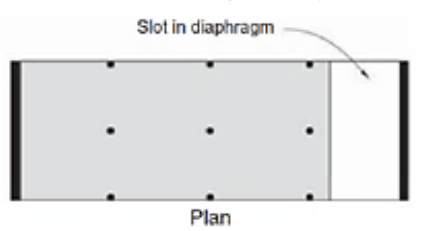

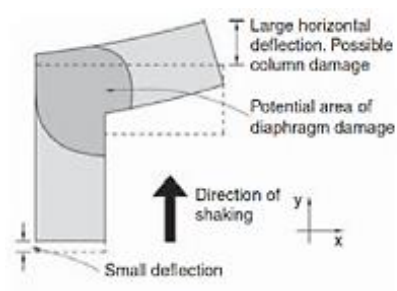

Re-entrant corner

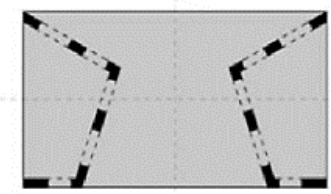

\footnotetext{
${ }^{8}$ Ibid., hlm. 27.

${ }^{9}$ Ching, F. D. (2014). Building Strucutres Illustrated Pattern, Systems, and Design: Second Edition. Canada: John Wiley \& Sons, hlm. 206.

${ }^{10}$ Japan Institute of Architects and Japan Aseismic Safety Organization. (2012). Earthquake-resistant Building Design for Architects Revised edition. Tokyo: SHOKOKUSHA Publishing Co., Ltd, hlm. 84

${ }^{11}$ Charleson, A., Op.cit, hlm. 63.

${ }^{12}$ Ibid., hlm. 49.

${ }^{13}$ Ibid., hlm. 125.

${ }^{14}$ Ibid., hlm. 143.
} 
Figur 3 Ketidakteraturan konfigurasi horizontal

Sumber: (Charleson, 2008)

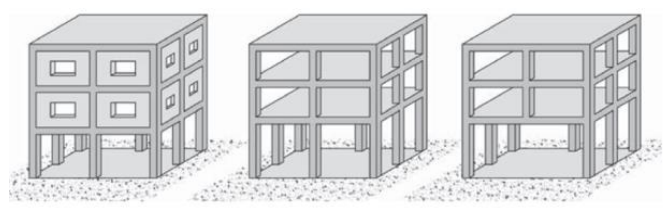

Soft story

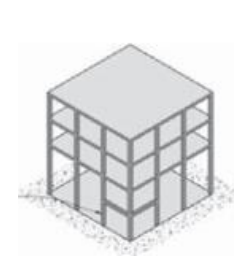

Short columns

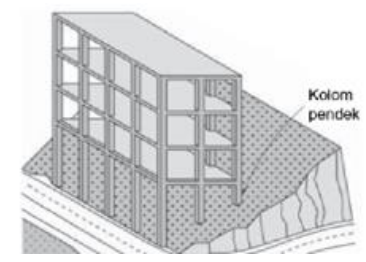

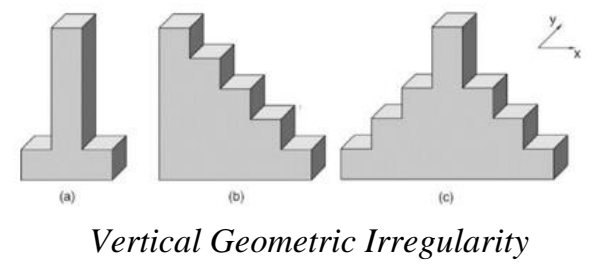

Figur 4 Ketidakteraturan konfigurasi vertikal

Sumber: (Charleson, 2008)

\section{METODE PENELITIAN}

Penelitian menggunakan metode deskriptif dengan pendekatan kualitatif. Metode deskriptif dilakukan dengan cara observasi objek studi yaitu Sopo Nagari Sihotang dengan mendeskripsikan keadaan eksistingnya. Pendekatan kualitatif menggunakan teori tektonika dan struktur tahan gempa dan dibandingkan dengan objek penelitian Sopo Nagari Sihotang. Data dikumpulkan dengan cara observasi lapangan dan studi pustaka. Observasi lapangan untuk mendapatkan data fisik dari Sopo Nagari Sihotang yang meliputi kondisi bangunan saat ini (material, kondisi struktur, kondisi sambungan, beban, umur dan ornamen) dan dimensi elemen struktur. Studi pustaka dilakukan untuk mengumpulkan data sopo yang meliputi fungsi, makna, dan gambar sopo. Data kemudian dikelompokkan menjadi empat bagian, yaitu konstruksi, detail, ruang, dan ornamen. Masing-masing akan dibagi lagi menjadi beberapa poin yang perlu diperlukan untuk membahas tektonika. Kemudian dilakukan analisis tektonika dikaitkan dengan teori struktur tahan gempa untuk mencari tahu apa yang membuat tektonika tersebut dapat resiliensi terhadap gempa bumi.

\section{RESILIENSI TEKTONIKA SOPO NAGARI SIHOTANG TERHADAP GEMPA BUMI}

\subsection{Tektonika Konstruksi}

Sopo Nagari Sihotang dibangun dengan menggunakan material kayu. Untuk elemen struktur digunakan jenis kayu keras yang merupakan material lokal berasal dari hutan di sekitarnya. Teknik konstruksi sopo adalah dengan cara menyusun dan menyambung material kayu tanpa menggunakan paku, tetapi dengan cara pen dan lubang, pasak, dan ikat. Dapat disimpulkan bahwa tektonika konstruksi Sopo Nagari Sihotang menggunakan sistem konstruksi tectonic.

Beban mati pada konstruksi elemen struktur vertikal sopo semakin ke atas semakin membesar karena dimensi struktur strukturnya yang semakin besar. Beban mati pada konstruksi elemen struktur horizontal sopo semakin ke atas semakin membesar meskipun dimensi elemen struktur konstruksi atas tidak sebesar konstruksi bawah, namun jumlahnya 
lebih banyak. Beban hidup lumbung padi pada lantai dua sopo lebih besar daripada beban manusia pada lantai satu.

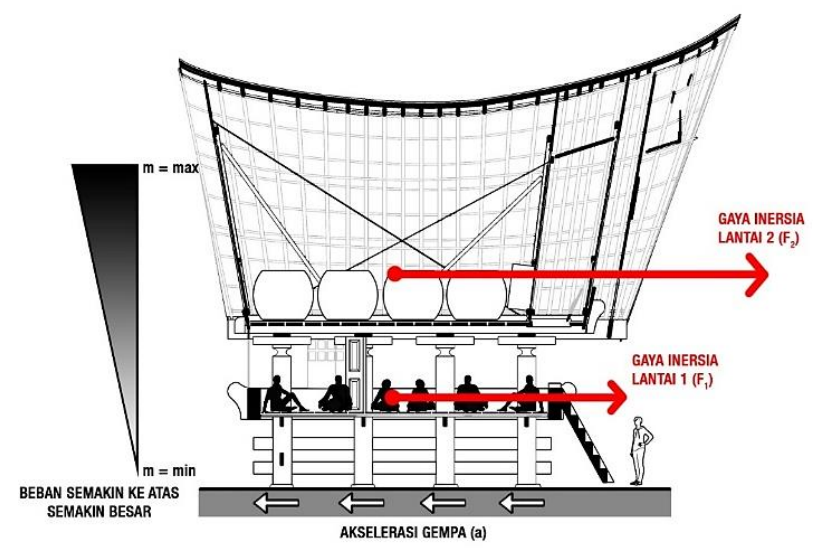

Figur 5 Gaya inersia pada sopo

Dari segi penggunaan material pada sistem konstruksi tectonic, memberikan keuntungan bagi sopo karena termasuk dalam tipe konstruksi ringan karena gaya inersia yang dialami sopo ketika terjadi gempa bumi menjadi berkurang. Beban hidup dan beban mati pada sopo semakin ke atas semakin membesar. Hal ini mempengaruhi besarnya gaya inersia (F), karena gaya inersia dipengaruhi oleh massa bangunan (m). Dengan asumsi bahwa nilai percepatan gempa (a) adalah sama, maka gaya inersia pada lantai dua sopo $\left(\mathrm{F}_{2}\right)$ akan lebih besar dibandingkan dengan lantai satu $\left(\mathrm{F}_{1}\right)$ sehingga beresiko merusak bangunan. Dapat disimpulkan bahwa tektonika konstruksi dengan sistem tectonic pada sopo memiliki resiliensi terhadap gempa bumi dari segi penggunaan material kayu. Dari segi pembebanan belum memiliki resiliensi terhadap gempa bumi.

\subsection{Tektonika Detail}

\subsubsection{Elemen Struktur Vertikal}

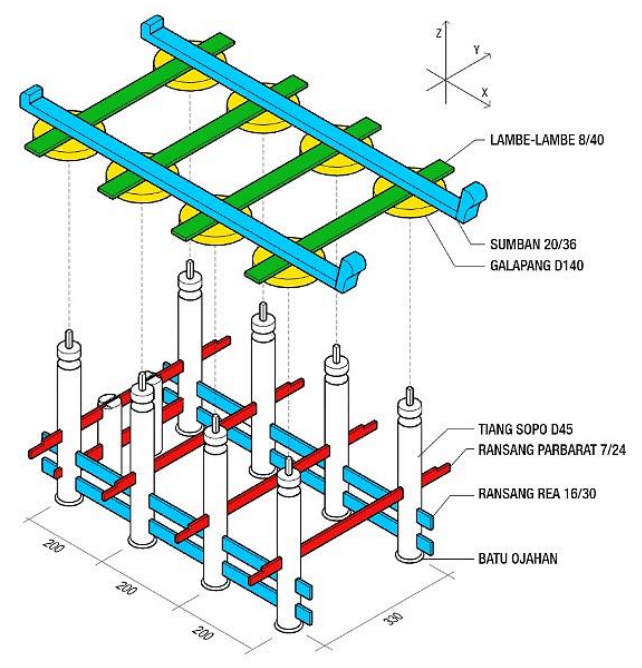

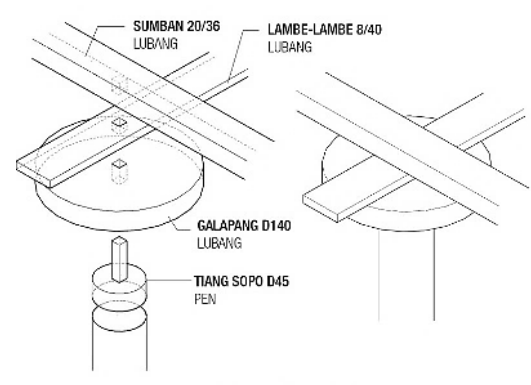

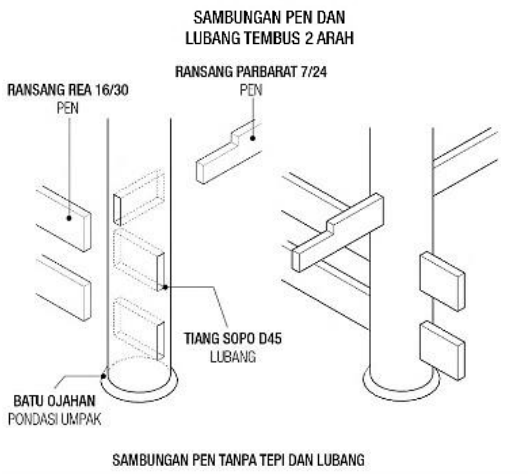

SAMBUNGAN PEN TANPA TEPI DAN LUBANG

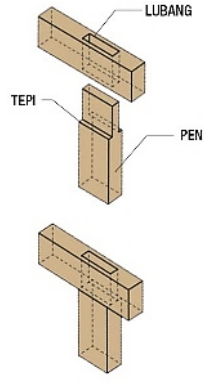

SAMBUNGAN PEN DAN LUBANG TEMBUS

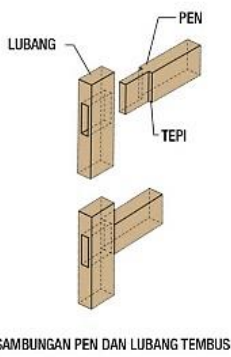


Figur 6 Elemen struktur vertikal dengan detail

Tiang sopo - batu ojahan (Error! Reference source not found. kanan bawah). Batu ojahan merupakan tipe pondasi umpak. Tiang sopo hanya diletakkan begitu saja di atas batu ojahan. Sambungan antara tiang sopo dengan batu ojahan diperlihatkan detailnya sehingga memperlihatkan kejujuran strukturnya. Pondasi umpak tipe sambungan sendi terbatas. Ketahanan sambungan terhadap gaya horizontal terbatas oleh gaya gesek antara batu ojahan dengan tiang sopo. Jika sudah melampaui batas gaya gesek, tipe sambungan akan berubah dari sendi terbatas menjadi rol.
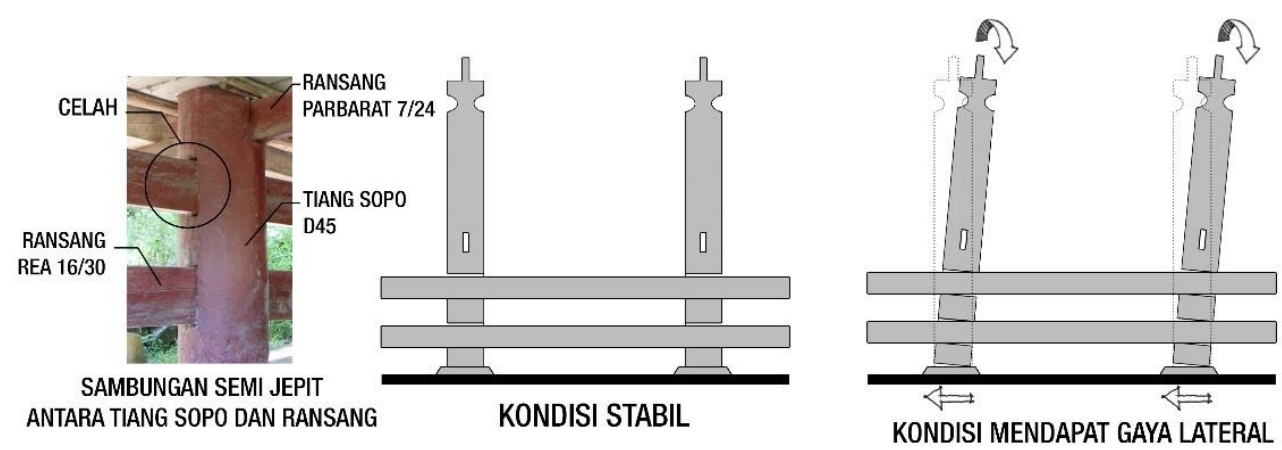

Figur 7 Sambungan semi jepit antara tiang sopo dan ransang

Tiang sopo - ransang (Error! Reference source not found. kanan bawah). Tiang sopo dihubungkan antara satu sama lain dengan menggunakan ransang rea dan ransang parbarat. Dimensi ransang rea lebih besar dan jumlahnya lebih banyak karena menghubungkan empat tiang sopo sedangkan ransang parbarat hanya menghubungkan dua tiang sopo saja. Perbedaan ini menunjukkan sudah terdapat kesadaran peran struktur terhadap gaya lateral. Detail sambungan antara tiang sopo dengan ransang adalah tipe pen dan lubang tembus tanpa tepi dengan pen-nya diteruskan hingga keluar melebihi lubang. Dapat disimpulkan bahwa sambungan antara tiang sopo dengan ransang memperlihatkan kejujuran strukturnya. Tiang sopo dengan ransang memiliki sambungan semi-jepit karena terdapat sedikit celah antara pada sambungannya, sehingga tiang sopo dapat bergoyang hingga seluruh celah pada sambungan tertutup oleh ransang (Figur 7). Saat celahnya tertutupi, maka sambungan menjadi jepit.

Tiang sopo - galapang, lambe-lambe, sumban (Error! Reference source not found. kanan atas) menggunakan prinsip sambungan pen dan lubang. Sambungan hanya menunjukkan kejujuran peran elemen struktur saja, sedangkan kejujuran detailnya tidak karena detailnya tidak terlihat. Sambungan ini merupakan sambungan sendi karena bentuk pen yang kecil. 


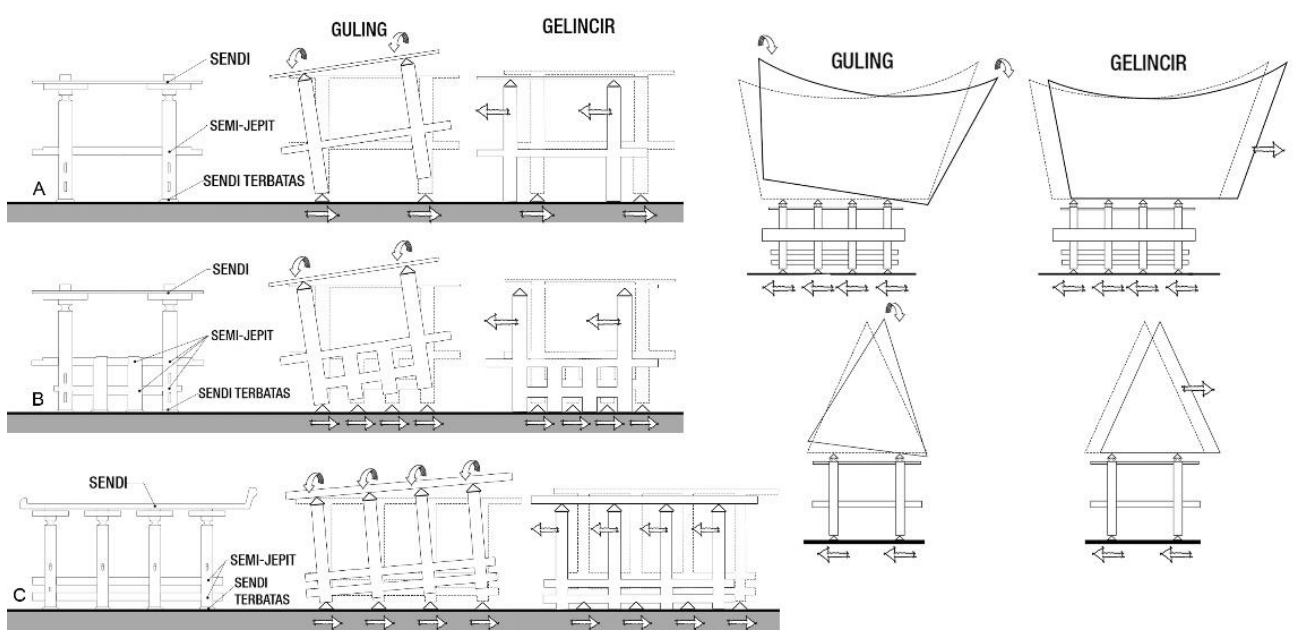

Figur 8 Reaksi elemen struktur vertikal terhadap gempa bumi

Resiliensi. Elemen struktur vertikal sopo sudah menggunakan sistem moment frame. Tektonika detail tiang sopo - batu ojahan dapat membuat struktur rawan terguling dan tergelincir (Figur 8). Struktur akan tergelincir jika melebihi batas gaya gesek dari tiang sopo, yang mengandalkan sistem berat sendiri. Tektonika detail tiang sopo - ransang dapat menahan gaya lateral dengan sambungan semi jepitnya. Tektonika detail tiang sopo galapang, lambe-lambe, sumban, dapat menahan gaya lateral dengan sambungan sendinya. Kesimpulan yang dapat ditarik adalah bukti bahwa sopo masih berdiri hingga saat ini menunjukkan bahwa tektonika detail pada tiang sopo - batu ojahan resiliensi terhadap gempa bumi dengan mengandalkan gaya gesek yang dihasilkan oleh sistem berat sendiri sopo. Tektonika detail pada tiang sopo - ransang dapat membuat struktur tetap kaku meskipun memungkinkan untuk bergerak sedikit.

\subsubsection{Elemen Struktur Horizontal}

Lantai satu (Figur 9 atas). Konstruksi lantai satu sopo terdiri dari tiga lapis konstruksi, yaitu ransang parbarat, balok lantai, dan papan kayu. dengan sistem penyaluran beban satu arah. Masing-masing lapisan konstruksi lantai disusun dengan cara ditumpuk langsung tanpa sambungan apapun. Di sekeliling lantai terdapat balok sombaho yang memperkaku bentuk lantai. Pada sudut pertemuan antar sombaho dihubungkan dengan menggunakan prinsip sambungan pen dan lubang dengan pasak. Sambungan pen dan lubang dengan pasak pada sombaho diekspose sehingga terlihat kejujuran strukturnya.

Lantai dua (Figur 9 bawah). Konstruksi lantai dua sopo terdiri dari tiga lapis konstruksi, yaitu sumban, gulang-gulang, dan lantai papan kayu. Perbedaannya dengan konstruksi lantai satu adalah pada orientasi kayunya. Konstruksi balok anak lantai dua jumlahnya lebih banyak dan jarak antar balok anaknya lebih rapat daripada lantai satu. Pertemuan antara gulang-gulang dengan tombonan urur dihubungkan dengan menggunakan prinsip sambungan pen dan lubang dengan pasak. Pen dari gulang-gulang tidak memiliki tepi sehingga sambungannya diekspose terlihat kejujuran strukturnya. 


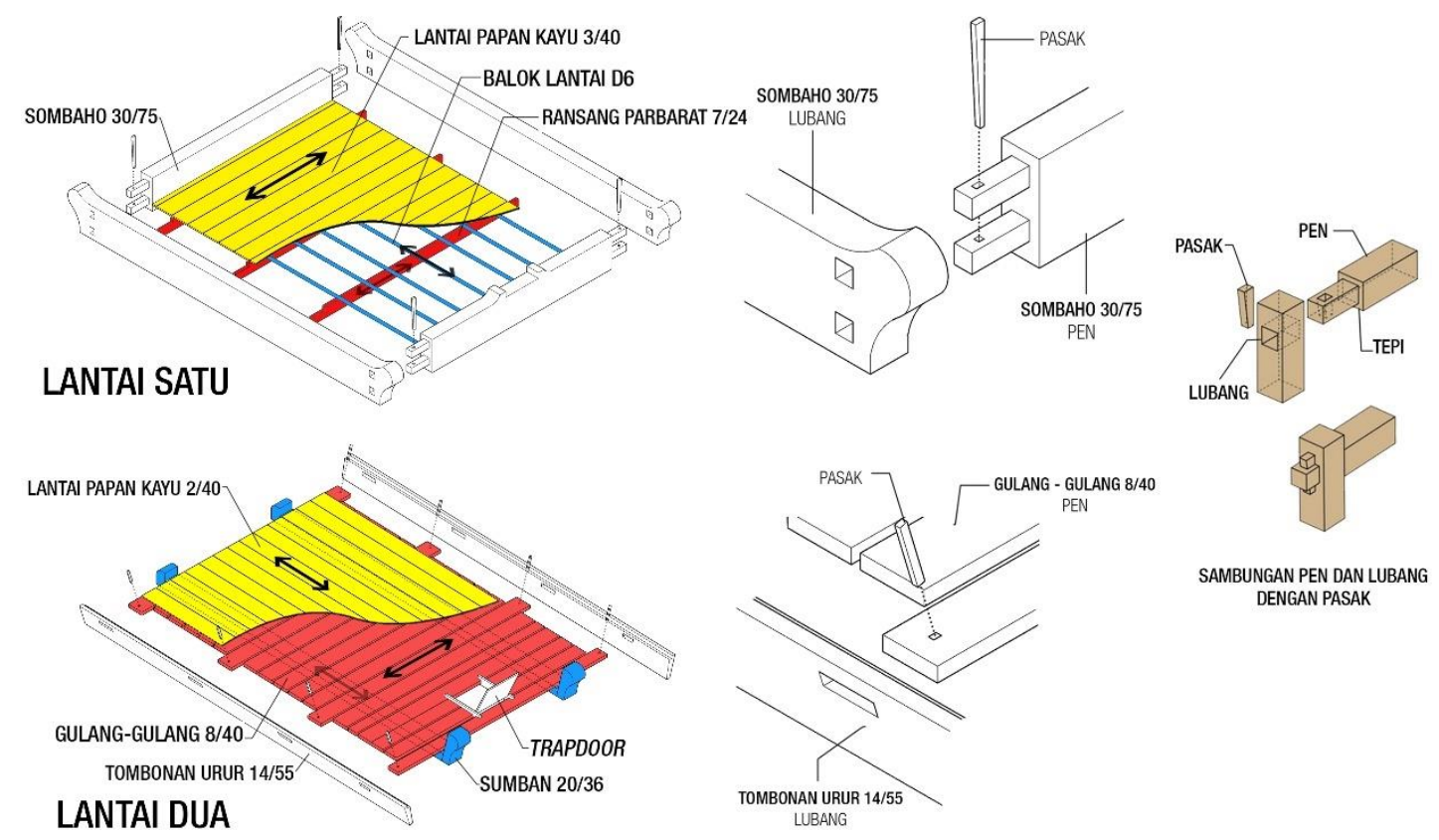

Figur 9 Konstruksi lantai satu dan lantau dua
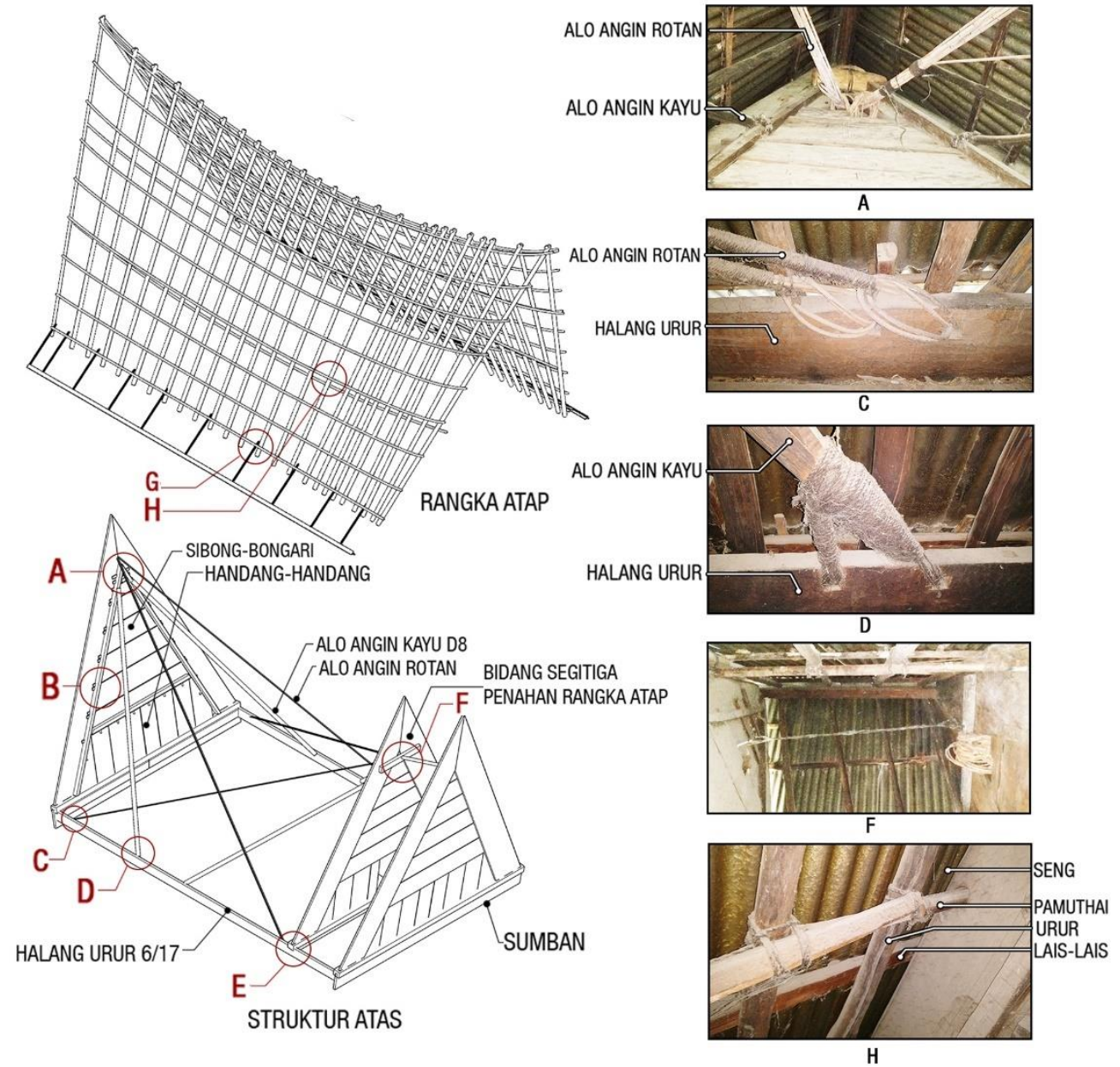

Figur 10 Konstruksi Atap dan detailnya

Atap (Figur 10). Konstruksi atap dimulai dari bidang segitiga pada bagian depan dan belakang sopo yang berfungsi sebagai kuda-kuda. Kedua bidang segitiga tersebut diletakkan dengan posisi mencondong ke arah luar, kemudian ditahan dengan menggunakan alo angin 
yang terbuat dari kayu dan rotan. Sambungan pada struktur atap dominan menggunakan sambungan ikat yang diekspose, gaya yang terjadi pada elemen struktur atap dominan gaya tarik. Hal ini menunjukkan bahwa pada struktur atap memiliki kejujuran struktur.

Resiliensi. Struktur lantai dan atap sopo merupakan diafragma fleksibel karena menggunakan material kayu. Pada diafragma lantai satu dan atap tidak ditemukan adanya void. Pada diafragma lantai dua terdapat void berupa trapdoor yang berfungsi sebagai sirkulasi vertikal, tetapi sudah diberikan struktur tambahan untuk memperkuat area di sekitar void. Dengan demikian diafragma pada sopo tidak memiliki masalah diaphragm discontinuity. Sambungan antara atap dengan lantai dua, antara lantai dua dengan elemen struktur vertikal, dan antara lantai satu dengan elemen struktur vertikal adalah sambungan sendi terbatas. Diafragma sopo dapat menyalurkan beban lateral ke elemen struktur vertikal, kemudian disalurkan ke tanah. Pada Figur 11 menunjukkan penyaluran gaya lateral. Kesimpulan yang dapat ditarik adalah tektonika detail elemen struktur horizontal sopo resiliensi terhadap gempa bumi karena detail pada diafragma dapat menyalurkan beban lateral hingga ke tanah. 


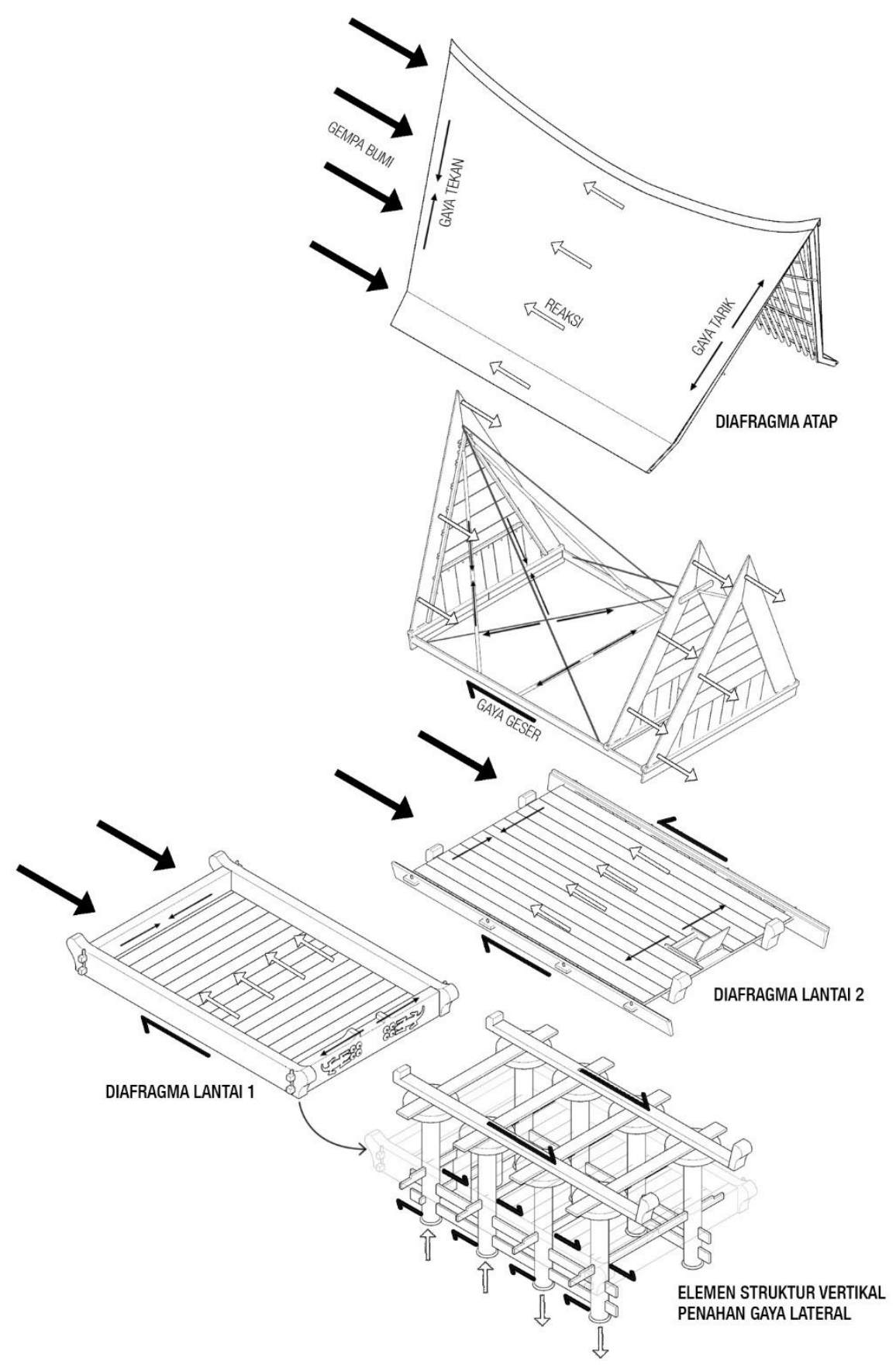

Figur 11 Gaya yang terjadi pada diafragma

\subsection{Tektonika Ruang}

Sopo dibagi menjadi tiga bagian ruang berdasarkan tri tunggal banua. Bagian atas Banua Ginjang (dunia atas) merupakan tempat para dewa. Bagian tengah Banua Tonga (dunia tengah) merupakan tempat bagi manusia. Bagian bawah Banua Toru (dunia bawah) merupakan tempat arwah dan roh jahat.

Ruang bagian bawah memiliki bentuk persegi panjang dengan ukuran panjang $6 \mathrm{~m}$ dan lebar 3,3 m. Ketinggian ruang adalah 1,48 m karena menyesuaikan dengan ketinggian pundak sapi dan kerbau yang rata-rata adalah 1,3 $\mathrm{m}$ (dulu digunakan untuk memelihara hewan ternak). 

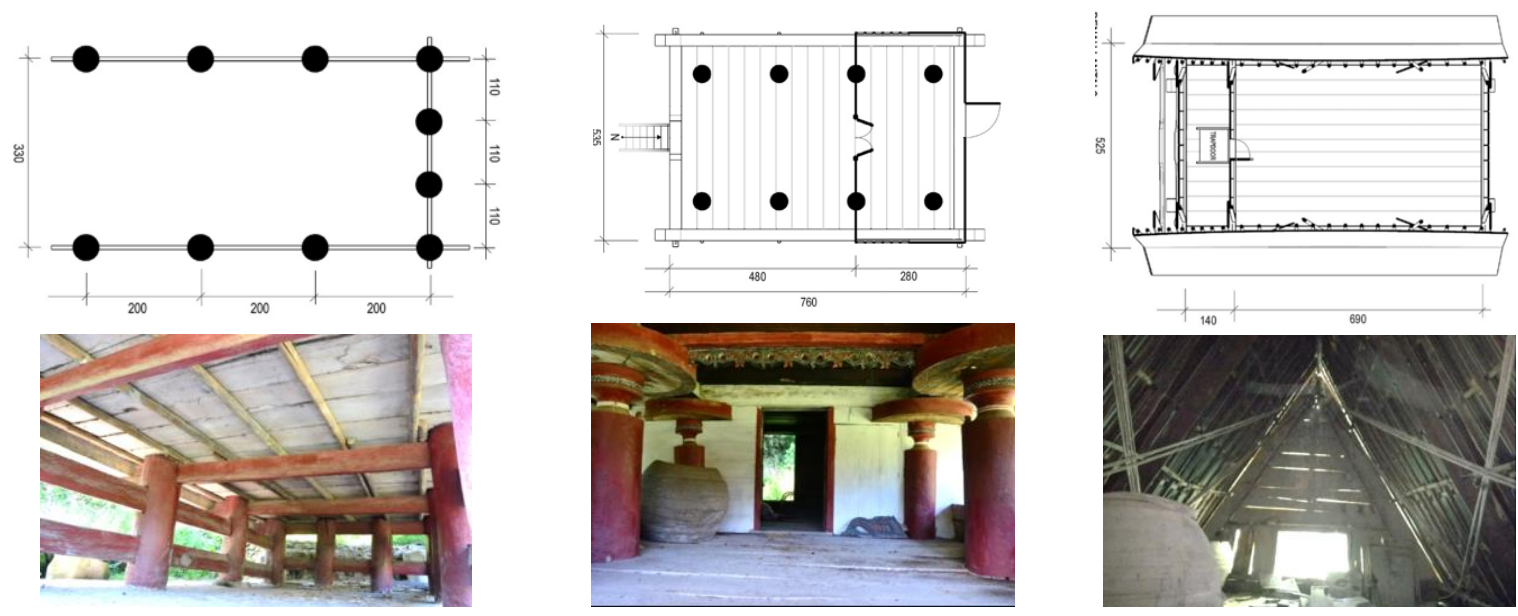

Figur 12 Ruang bagian bawah (kiri), bagian tengah (tengah), dan bagian atas (kanan)

Ruang bagian tengah sopo terbagi menjadi dua ruang. Ruang pertama berada di depan berbentuk persegi panjang dengan ukuran panjang 4,8 $\mathrm{m}$ dan lebar 5,35 m. Ruang kedua adalah ruang tertutup di belakang dengan bentuk persegi panjang berukuran panjang 2,8 m dan lebar 5,35 $\mathrm{m}$. Aktivitas di ruang ini sering dilakukan dalam kondisi duduk, sehingga ketinggian ruang cenderung rendah, yaitu $1,85 \mathrm{~m}$.

Ruang bagian atas berada di atap sopo. Ruang ini berbentuk persegi panjang dengan ukuran panjang $8,3 \mathrm{~m}$ dan lebar 5,25 $\mathrm{m}$. Ruang terbagi menjadi dua, ruang pertama adalah ruang perantara setelah naik melalui trapdoor dengan ukuran panjang 1,4 $\mathrm{m}$ dan lebar 5,25 $\mathrm{m}$, dan ruang kedua adalah ruang tempat menyimpan lumbung padi dengan ukuran ruang panjang $6,9 \mathrm{~m}$ dan lebar 5,25 $\mathrm{m}$. Bagian dalam ruang ini berbentuk segitiga mengikuti bentuk atapnya. Ruang ini memiliki jarak floor to ceiling yang tinggi, yaitu $5 \mathrm{~m}$ untuk titik terendah dan 5,5 m untuk titik tertinggi. Ketinggian ruang ini dipengaruhi budaya orang Batak membuat bentuk atap sopo seperti punggung kerbau yang melengkung.

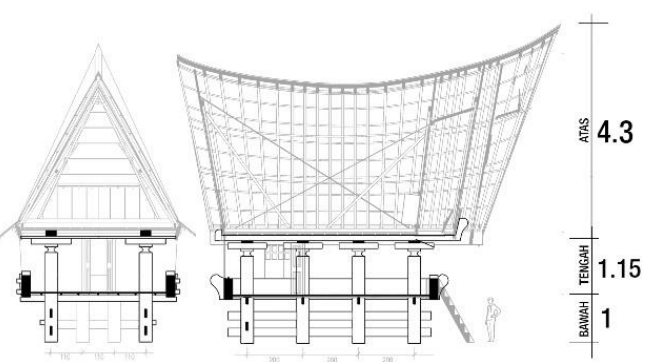

Figur 13 Proporsi tinggi lantai dan kolom

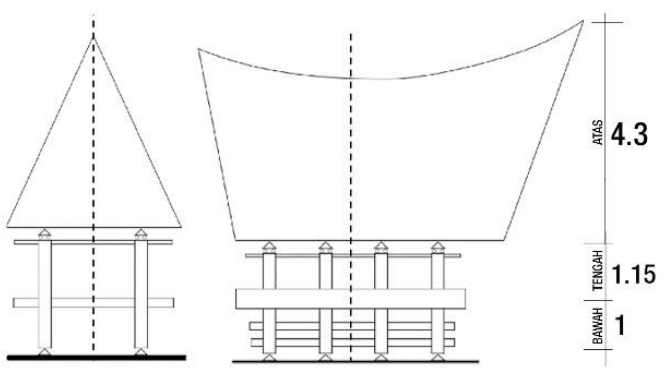

Figur 14 Geometri Vertikal Sopo

Ketinggian ruang - aktivitas. Ketinggian ruang yang dipengaruhi oleh aktivitas menghasilkan proporsi yang hampir sama antara bagian bawah dengan badan tengah, yaitu 1:1,15 (Figur 13). Proporsi ini membuat tiang sopo sama-sama kaku pada bagian bawah maupun bagian tengah, sehingga tektonika ruang sopo tidak memiliki ketidakteraturan soft story. Proporsi ketinggian tiang juga sama antara ruang bagian bawah dan ruang bagian. Sopo dibangun di tanah yang datar, sehingga semua tiang sopo sama tingginya. Dapat disimpulkan tektonika ruang sopo tidak memiliki ketidakteraturan short columns.

Bentuk ruang - bentuk bangunan. Sopo dibentuk seperti kerbau, atap yang melengkung adalah punggung kerbau dan tiang-tiang pada kolong sopo adalah kaki kerbau. 
Konsekuensinya berpengaruh terhadap bentuk ruang. Atap sopo memiliki bentuk trapesium melengkung, namun tidak ditemukan re-entrant corner dan bentuk hampir simetris (Figur 14). Elemen garis pada bagian bawah berbentuk persegi panjang. Tidak ditemukan adanya reentrant corner pada geometri vertikal sopo sehingga tektonika ruang sopo tidak memiliki vertical geometric irregularity. Bentuk sopo seperti kerbau juga berpengaruh terhadap bentuk denah sopo. Bentuk denah sopo persegi panjang dan tidak ada re-entrant corner (Figur 15). Perbandingan proporsi panjang dan lebar denah adalah 1:1,8. Proporsi ini masih berada di bawah 1:2, sehingga tidak terlalu panjang. Dapat disimpulkan bahwa tektonika ruang sopo tidak memiliki penyimpangan re-entrant corner.
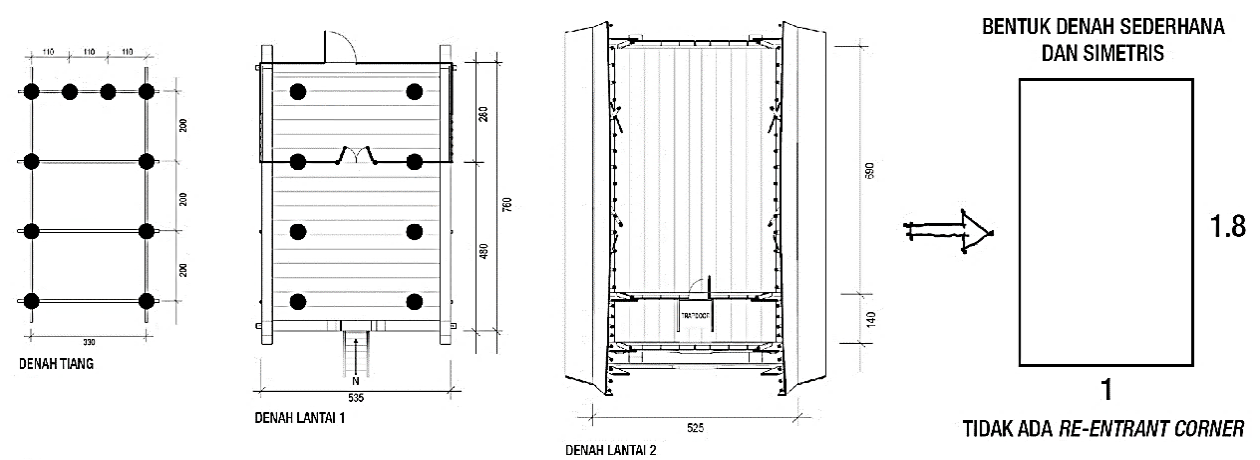

Figur 15 Re-entrant corner sopo

Bentuk ruang - susunan struktur. Sopo dibentuk seperti kerbau terlebih dahulu, kemudian ditambahkan struktur yang sesuai dengan bentuknya. Peletakan tiang sopo paralel terhadap sumbu $\mathrm{x}$ dan y (Figur 16), sehingga tiang sopo dapat menahan gaya lateral dari arah $\mathrm{x}$ dan $\mathrm{y}$. Posisi tiang sopo terhadap bentuk denah tidak memiliki masalah non-parallel systems.

Pada denah bagian bawah terlihat susunan tiang sopo lebih banyak di bagian belakang (4 tiang) daripada depan (2 tiang), akibatnya bagian belakang menjadi lebih kaku (Figur 17). Oleh karena itu, CoR bergeser ke belakang dan CoM tetap berada di tengah, akibatnya terdapat eksentrisitas pada sumbu $\mathrm{Y}$ yang menyebabkan terjadi torsi. Pada denah bagian tengah, susunan tiang sopo simetris pada sumbu X maupun sumbu Y, CoR dan CoM berada pada satu titik dan nilai eksentrisitas nol. Maka, pada denah bagian tengah tidak terjadi torsi. Pada denah bagian atas memiliki bentuk denah simetris, susunan tiang sopo di bawahnya yang menopang lantai juga simetris pada sumbu X dan Y. CoR dan CoM berada pada satu titik dan nilai eksentrisitasnya nol, maka tidak terjadi torsi. Dari pembahasan di atas, dapat disimpulkan bahwa tektonika ruang sopo memiliki penyimpangan plan irregularity pada ruang bagian bawah. 


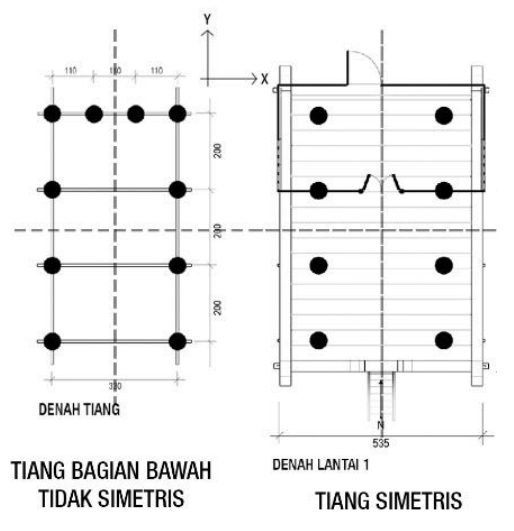

Figur 16 Tiang sopo parallel
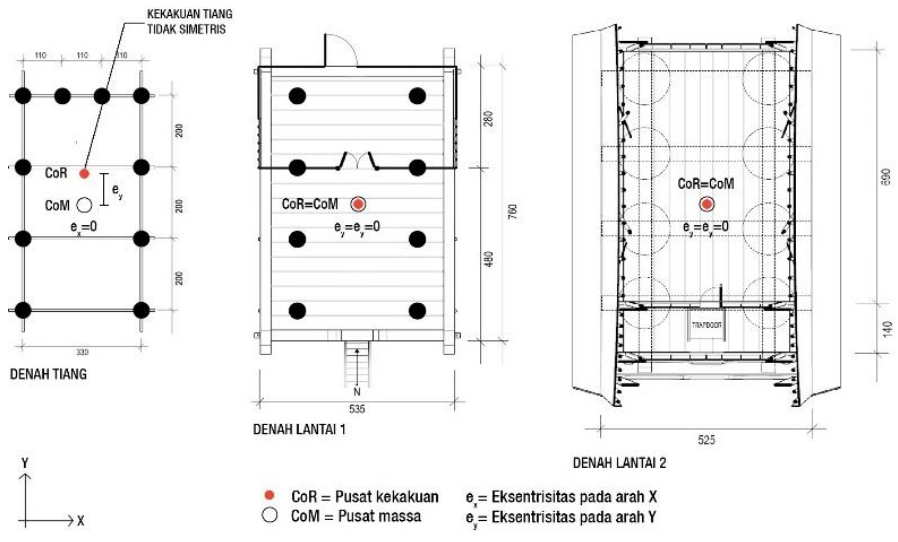

Figur 17 Pusat massa dan pusat kekakuan pada setiap lantai

Aktivitas - susunan struktur. Ruang bagian atas dulunya digunakan untuk menyimpan padi dan barang-barang untuk upacara. Jika bagian atas sopo ini difungsikan seperti dulunya makan akan menerima beban yang besar dari lumbung padi yang disimpan. Beban lumbung ini dapat mempengaruhi titik pusat massa bangunan tergantung dari cara menyusun padi tersebut.

Cara menyusun pertama (Figur 18, atas) adalah padi disusun hingga penuh dahulu pada bagian belakang. Cara ini dapat menggeser CoM sehingga terdapat jarak antara CoM dan CoR. Terdapat eksentrisitas yang menimbulkan torsi saat terjadi gempa bumi. Cara menyusun kedua (Figur 18, bawah) adalah padi disusun merata. Bila padi disusun dengan cara ini $\mathrm{CoM}$ akan tetap berada di tengah. CoM akan tetap berhimpit dengan CoR, sehingga tidak menimbulkan torsi. Saat ini ruang lantai dua sudah tidak digunakan lagi untuk menyimpan lumbung pada, maka dapat disimpulkan bahwa CoR dan pusat massa CoM berada pada satu titik dan tidak terjadi torsi, sehingga tidak memiliki ketidakteraturan mass irregularity. 

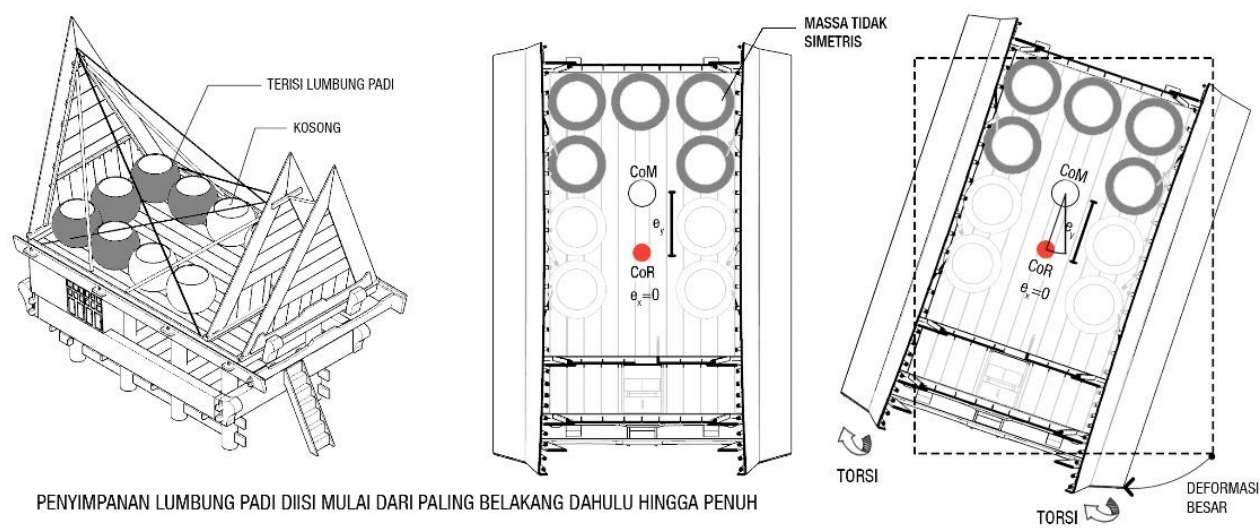

PENYIMPANAN LUMBUNG PADI DIISI MULAI DARI PALING BELAKANG DAHULU HINGGA PENUH
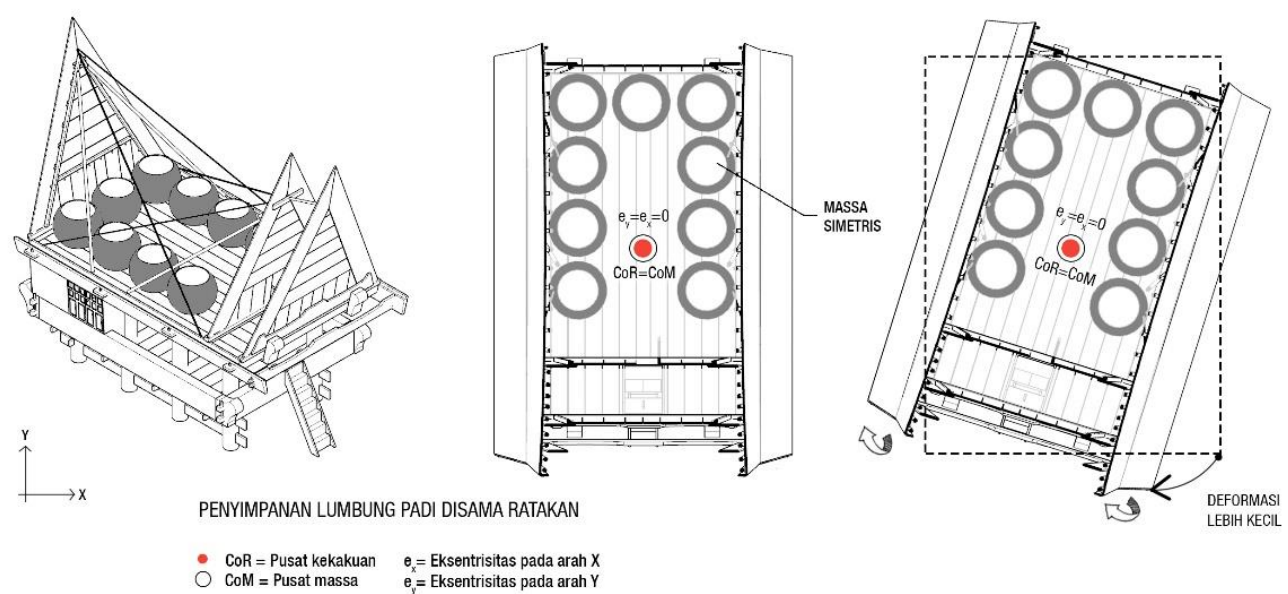

Figur 18 Pengaruh susunan lumbung padi pada pusat massa (CoM) dan pusat kekakuan $(\mathrm{CoR})$

\subsection{Tektonika Ornamen}

Ornamen dalam Batak Toba disebut dengan Gorga, yang memiliki arti kesenian ukir atau pahat yang terdapat pada bagian luar bangunan Batak Toba dan alat kesenian, dan sebagainya. Ornamen lengkap di rumah raja saja, sedangkan pada rumah penduduk biasa tidak lengkap. Ornamen digunakan untuk menambah nilai estetika pada bangunan dan menunjukkan status sosial. Ornamen di setiap kampung selalu dibuat oleh orang yang berbeda, sehingga bentuk ornamen tidak ada yang sama. Ornamen terbagi menjadi dua, yaitu ornamen non-struktural dan structural.

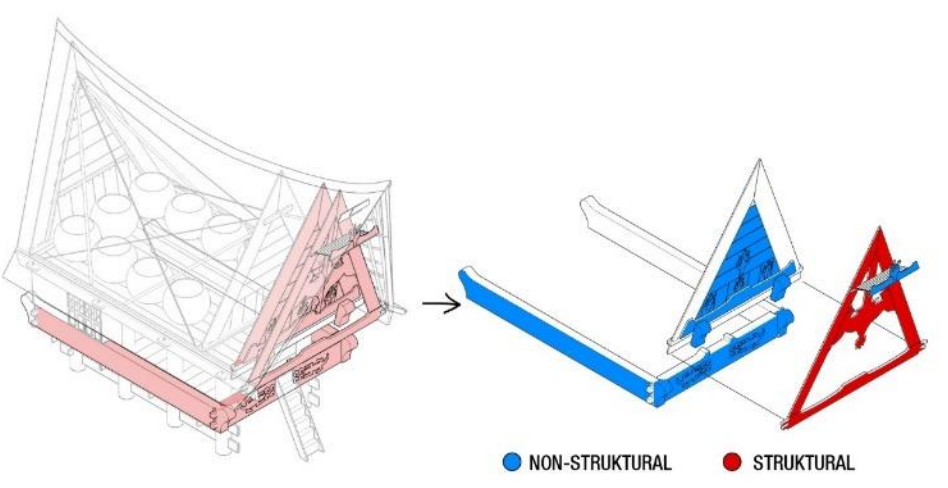

Figur 19 Pembagian ornamen pasif dan aktif

Ornamen non-struktural. Ornamen singa-singa pada Figur 21(5 dan 12) merupakan ornamen paling besar. Kata singa bukan berarti binatang buas, melainkan berwibawa dan berkharisma. Singa-singa memiliki bentuk seperti wajah manusia yang berwibawa dengan 
lidah terjurai ke bawah dan kaki berlutut. Ornamen boraspati (cedak) pada Figur 21(7) merupakan ornamen dengan bentuk seperti biawak kecil yang ujung ekornya hanya bercabang satu. Ornamen ini melambangkan kekuatan untuk melindungi harta kekayaan manusia dan melipatgandakannya. Ornamen susu pada Figur 21(7) merupakan ornamen dengan bentuk seperti payudara wanita. Ornamen ini melambangkan kesuburan dan kekayaan, juga dikatakan sebagai lambang keibuan sebagai pengasih dan penyayang, atau dalam bahasa Batak Toba "Inanta parsonduk bolon".

Ornamen struktural. Ornamen jenggar dapat dikategorikan sebagai ornamen struktural karena bentuknya yang segitiga dapat membantu memperkaku struktur atap bagian depan, dan sebagai tempat menumpu pamuthai (gording). Tetapi struktur atap masih dapat tetap stabil tanpa ornamen ini karena jenggar terhubung oleh alo angin pada struktur atap, sehingga struktur atap tetap menerima beban lebih besar

Resiliensi. Posisi ornamen non-struktural pada sopo berada pada sombaho dan bidang segitiga atap bagian depan saja. Makna ornamen tersebut tidak memiliki hubungan terhadap struktur sopo, sehingga dapat disimpulkan bahwa tektonika ornamen non struktural tidak memiliki resiliensi terhadap gempa bumi. Ornamen struktural pada sopo ini bukan merupakan elemen struktur penahan gaya lateral. Ketika terjadi gempa, gaya lateral yang pada struktur atap akan lebih banyak ditahan oleh struktur atap daripada jenggar karena bidang segitiga lebih kaku daripada jenggar. Sehingga dapat disimpulkan bahwa tektonika ornamen struktural tidak memiliki resiliensi terhadap gempa bumi.
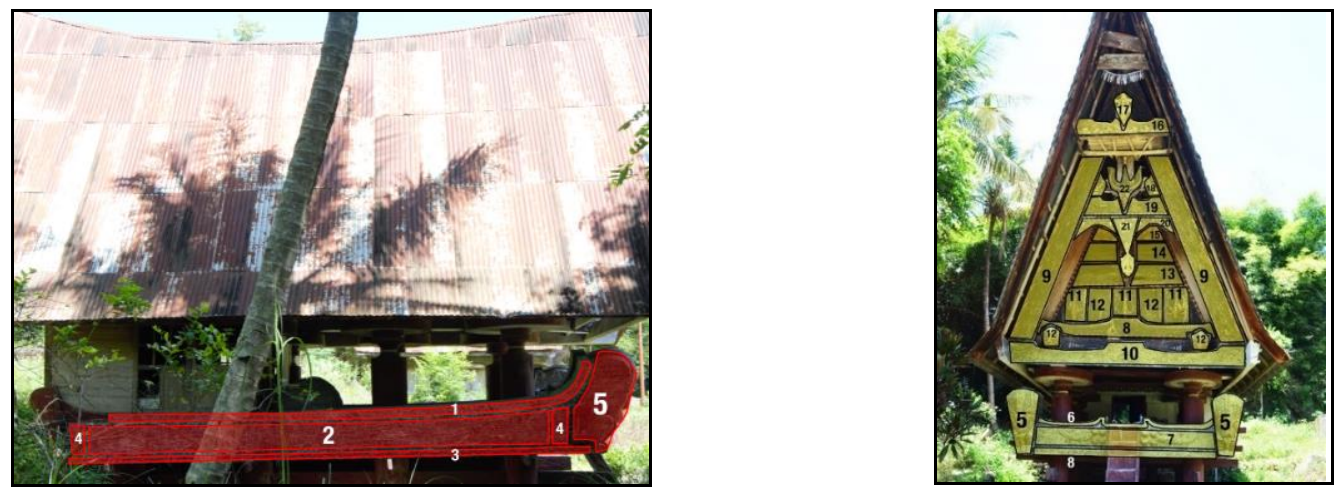

Figur 20 Posisi ornamen

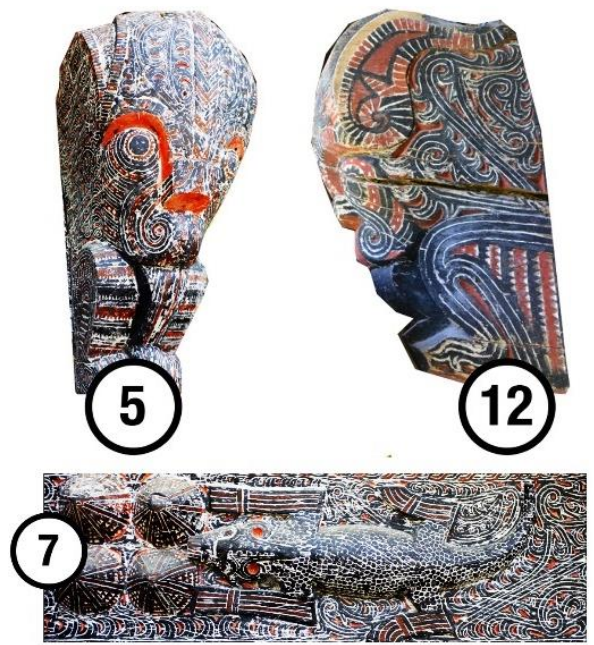

Figur 21 Detail ukiran ornamen

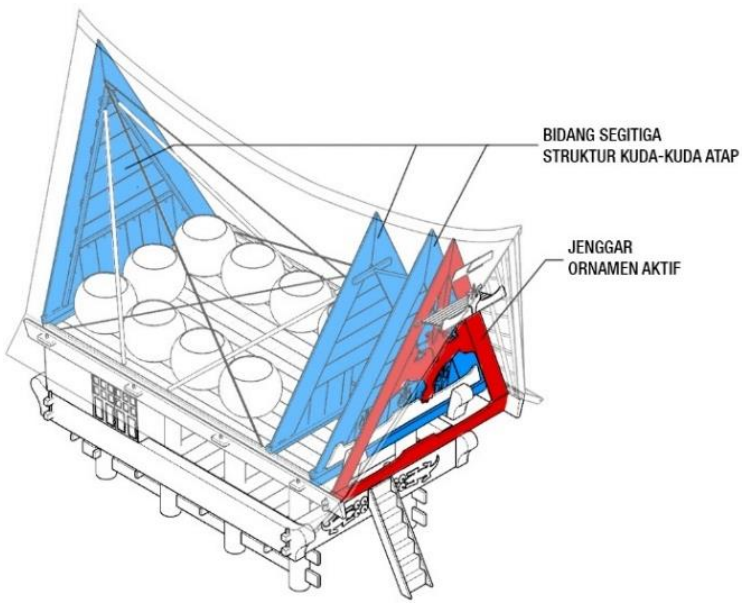

Figur 22 Ornamen struktural jenggar terhadap struktur atap 


\subsection{Rangkuman}

Tabel 1 Hasil analisis tektonika konstruksi Sopo Nagari Sihotang terhadap gempa bumi

\section{Tektonika Konstruksi}

\begin{tabular}{|l|l|}
\hline \multicolumn{1}{|c|}{ Tektonika } & \multicolumn{1}{c|}{ Resiliensi tektonika terhadap gempa } \\
\hline $\begin{array}{l}\text { Tektonika konstruksi sopo } \\
\text { merupakan sistem konstruksi } \\
\text { tectonic. }\end{array}$ & $\begin{array}{l}\text { Sistem konstruksi tectonic dengan material kayu memiliki resiliensi terhadap } \\
\text { gempa bumi karena membuat keseluruhan struktur bangunan menjadi ringan, } \\
\text { sehingga mengurangi gaya inersia. }\end{array}$ \\
& $\begin{array}{l}\text { Dari segi beban hidup dan beban mati tidak memiliki resiliensi terhadap } \\
\text { gempa bumi karena besarnya gaya inersia pada bagian atas sopo akibat dari } \\
\text { beban yang semakin ke atas semakin besar. }\end{array}$ \\
\hline
\end{tabular}

Tabel 2 Hasil analisis tektonika detail Sopo Nagari Sihotang terhadap gempa bumi

\begin{tabular}{|c|c|}
\hline \multicolumn{2}{|c|}{ Tektonika Detail } \\
\hline \multicolumn{2}{|c|}{ Elemen Struktur Vertikal } \\
\hline Tektonika & Resiliensi tektonika terhadap gempa \\
\hline $\begin{array}{l}\text { Penyelesaian pertemuan antara dua elemen } \\
\text { struktur menghasilkan detil sambungan yang } \\
\text { memiliki intensi untuk memperlihatkan kejujuran } \\
\text { struktur dengan cara mengekspose detail } \\
\text { sambungan. } \\
\text { Tipe sambungan yang dihasilkan dari pengolahan } \\
\text { detail sambungan adalah tiang sopo - batu ojahan } \\
\text { tipe sendi terbatas, tiang sopo-ransang tipe semi } \\
\text { jepit, dan tiang sopo - galapang, lambe-lambe, } \\
\text { sumban tipe sendi. }\end{array}$ & $\begin{array}{l}\text { Tiang sopo terlihat menerus dari atas hingga ke bawah } \\
\text { sehingga tidak terjadi discontinuous and off-set walls } \\
\text { Sambungan semi jepit pada tiang sopo - ransang membuat } \\
\text { elemen struktur vertikal menjadi kaku dan dapat menahan } \\
\text { gaya lateral dari gempa bumi. } \\
\text { Sambungan sendi terbatas pada tiang sopo - batu ojahan } \\
\text { mengandalkan sistem berat sendiri sopo yang } \\
\text { menghasilkan gaya gesekan antara dasar tiang sopo } \\
\text { dengan batu ojahan. }\end{array}$ \\
\hline \multicolumn{2}{|c|}{ Elemen Struktur Horizontal } \\
\hline Tektonika & Resiliensi tektonika terhadap gempa \\
\hline $\begin{array}{l}\text { Susunan konstruksi lantai sopo dilakukan dengan } \\
\text { cara menumpuk setiap elemen menjadi tiga lapis } \\
\text { kosntruksi. }\end{array}$ & $\begin{array}{l}\text { Lantai dan atap yang diinstruksikan dapat berfungsi } \\
\text { sebagai diafragma. Pada diafragma tidak terdapat } \\
\text { diaphragm discontinuity. }\end{array}$ \\
\hline $\begin{array}{l}\text { Susunan konstruksi atap sopo dilakukan denganc } \\
\text { cara menumpuk dan mengikat elemen struktur. } \\
\text { Terdapat beberapa detail sambungan yang } \\
\text { diekspose untuk menunjukkan kejujuran struktur }\end{array}$ & $\begin{array}{l}\text { Tektonika detail sambungan antara diafragma dengan } \\
\text { elemen struktur vertikal memiliki resiliensi terhadap } \\
\text { gempa bumi dengan mengandalkan gaya gesek pada } \\
\text { sambungan sendi terbatas. Gaya lateral yang terjadi pada } \\
\text { diafragma dapat tersalurkan dengan baik hingga ke } \\
\text { pondasi. }\end{array}$ \\
\hline
\end{tabular}

Tabel 3 Hasil analisis tektonika ruang Sopo Nagari Sihotang terhadap gempa bumi

\begin{tabular}{|c|c|}
\hline & Tektonika Ruang \\
\hline \multicolumn{2}{|r|}{ Ketinggian Ruang - Aktivitas } \\
\hline Tektonika & Resiliensi tektonika terhadap gempa \\
\hline $\begin{array}{l}\text { Ketinggian ruang yang terbentuk } \\
\text { menyesuaikan dengan aktivitas dan } \\
\text { mempengaruhi proporsi tinggi kolom } \\
\text { dan proporsi tinggi story antar lantai. }\end{array}$ & $\begin{array}{l}\text { Proporsi tinggi kolom antar lantai hampir sama sehingga tidak } \\
\text { memiliki short columns. } \\
\text { Proporsi tinggi story antar lantai memiliki proporsi yang hampir } \\
\text { sama sehingga tidak terbentuk soft story. }\end{array}$ \\
\hline \multicolumn{2}{|r|}{ Bentuk Ruang - Bentuk Bangunan } \\
\hline Tektonika & Resiliensi tektonika terhadap gempa \\
\hline $\begin{array}{l}\text { Bentuk massa sopo merupakan } \\
\text { penafsiran dari bentuk kerbau. Massa }\end{array}$ & $\begin{array}{l}\text { Penafsiran bentuk massa sopo terhadap bentuk kerbau menghasilkan } \\
\text { bentuk geometris dasar dan simteris, sehingga tidak terdapat vertical }\end{array}$ \\
\hline
\end{tabular}




\begin{tabular}{|l|l|}
\hline $\begin{array}{l}\text { yang terbentuk juga mempengaruhi } \\
\text { bentuk ruang. }\end{array}$ & $\begin{array}{l}\text { geometric irregularity. } \\
\text { Bentuk denah yang dihasilkan dari penafsiran bentuk kerbau adalah } \\
\text { bentuk persegi panjang dan tidak memiliki re-entrant corner dan } \\
\text { memiliki proporsi yang baik. }\end{array}$ \\
\hline \multicolumn{2}{|c|}{ Bentuk Ruang - Susunan Struktur } \\
\hline $\begin{array}{l}\text { Tektonika } \\
\text { dahulu agar memiliki korelasi dengan } \\
\text { kerbau, kemudian baru ditambahkan } \\
\text { struktur yang sesuai dengan bentuk } \\
\text { sopo tersebut }\end{array}$ & $\begin{array}{l}\text { Peletakan struktur sopo parallel terhadap bentuk denah sopo, } \\
\text { sehingga tidak memiliki masalah non-parallel systems } \\
\text { Peletakan struktur sopo pada denah bagian bawah memiliki masalah } \\
\text { plan irregularity sehingga menyebabkan terjadinya torsi. }\end{array}$ \\
\hline $\begin{array}{l}\text { Tektonika } \\
\text { Aktivitas - Susunan Struktur }\end{array}$ \\
\hline $\begin{array}{l}\text { Pembagian aktivitas sopo pada setiap } \\
\text { ruang dapat mempengaruhi struktur } \\
\text { sopo karena ketika terjadi aktivitas di } \\
\text { dalam ruang maka ada tambahan beban } \\
\text { hidup. }\end{array}$ & $\begin{array}{l}\text { Saat ini tidak terjadi masalah mass irregulariy karena ruang bagian } \\
\text { atas sopo sudah tidak digunakan lagi. }\end{array}$ \\
\hline
\end{tabular}

Tabel 4 Hasil analisis tektonika ornamen Sopo Nagari Sihotang terhadap gempa bumi

\begin{tabular}{|l|c|}
\hline \multicolumn{3}{|c|}{ Tektonika } & \multicolumn{1}{|c|}{ Tektonika Ornamen } \\
\hline $\begin{array}{l}\text { Hubungan antara konstruksi bangunan yang tektonika terhadap gempa } \\
\text { dibutuhkan untuk stabilitas bangunan dengan } \\
\text { ornamen yang digunakan untuk menambahkan } \\
\text { nilai estetika. }\end{array}$ & $\begin{array}{l}\text { Tektonika ornamen non-struktural dan ornamen struktural } \\
\text { tidak memiliki resiliensi terhadap gempa bumi. }\end{array}$ \\
\hline
\end{tabular}

\section{KESIMPULAN}

Dari hasil penelitian yang telah dilakukan, dapat ditarik kesimpulan berkaitan berkaitan dengan tektonika Sopo Nagari Sihotang dan resiliensinya terhadap gempa bumi. Resiliensi tektonika Sopo Nagari Sihotang terhadap gempa bumi ditemukan pada tektonika konstruksi dalam penggunaan material; tektonika detail pada elemen struktur vertikal dan elemen struktur horizontal; dan tektonika ruang pada ketinggian ruang - aktivitas, bentuk ruang bentuk bangunan, bentuk ruang - susunan struktur, dan bentuk ruang - susunan struktur. Resiliensi tektonika Sopo Nagari Sihotang terhadap gempa bumi tidak ditemukan pada tektonika konstruksi dalam pembebanan sopo dan tektonika ornamen.

Terdapat temuan kearifan lokal yang merupakan faktor utama membuat sopo resiliensi terhadap gempa bumi. Kearifan lokal pada tektonika detail bagian elemen struktur vertikal, pada pengolahan sambungan antara tiang sopo - batu ojahan dan tiang sopo - ransang. Pengolahan detail sambungan tiang sopo - batu ojahan dapat mempertahankan sopo agar tidak terguling maupun tergelincir dengan mengandalkan gaya gesek yang dihasilkan dari berat sendiri sopo. Pengolahan detail sambungan tiang sopo - ransang berhasil mengikat antar tiang sopo. Tiang sopo masih berdiri hingga saat ini meskipun tipe sambungan memungkinkan tiang sopo untuk sedikit bergerak saat terjadi gempa bumi. Sopo ini menggunakan kayu sebagai material utamanya pada elemen struktur maupun elemen nonstruktur. Kayu merupakan material yang ringan, sehingga dapat mengurangi besarnya gaya lateral yang terjadi akibat gempa bumi. 


\section{PENUTUP}

Saran pada penelitian ini lebih ditujukan peneliti selanjutnya yang ingin meneliti Sopo Nagari Sihotang. Masih ada aspek yang belum diteliti lagi mengenai sopo ini karena keterbatasan waktu dan data. Berkaitan dengan resiliensi tektonika Sopo Nagari Sihotang terhadap gempa bumi, aspek tektonika tempat (place) yang merupakan studi hubungan antara bangunan dengan tapak atau konsteksnya belum diteliti karena kekurangan data. Dari hasil kesimpulan penelitian ini juga dapat dilakukan penelitian lebih lanjut lagi dalam ranah arsitektur maupun teknik sipil, yaitu tentang kekuatan sambungan tiang sopo dengan batu ojahan dan kekuatan sambungan tiang sopo dengan ransang.

\section{ACUAN}

Charleson, A. (2008). Seismic Design for Architects. USA: Architectural Press.

Ching, F. D. (2012). A Visual Dictionary of Architecture Second Edition. Canada: John Wiley \& Sons, Inc.

Ching, F. D. (2014). Building Strucutres Illustrated Pattern, Systems, and Design: Second Edition. Canada: John Wiley \& Sons.

Earthquake Engineering Research Institute. (2006). Designing for Earthquakes: A Manual for Architects. Oakland: FEMA.

Frampton, K. (1995). Studies in Tectonic Culture. Chicago: The MIT Press.

Japan Institute of Architects and Japan Aseismic Safety Organization. (2012). Earthquake-resistant Building Design for Architects Revised edition. Tokyo: SHOKOKUSHA Publishing Co., Ltd.

Resilient Design Institute. (2013). Resilient Design Strategies. Dipetik Februari 2, 2018, dari Resilient Design Institute: http://www.resilientdesign.org/resilient-design-strategies/

Schwartz, C. J. (2016). Introducing Architectural Tectonics: Exploring the Intersection of Design and Construction. New York: Routledge, Taylor \& Francis Group. 